\title{
29. DATA REPORT: MAGNETIC MINERALOGY, MAJOR- AND TRACE-ELEMENT GEOCHEMISTRY, AND ROCK MAGNETIC PROPERTIES OF HOLE 504B UPPER CRUSTAL ROCKS
}

\author{
Laura B. Stokking, ${ }^{2}$ Elizabeth A. Heise, ${ }^{2}$ Janet E. Pariso, ${ }^{3}$ and Simon A. Allerton ${ }^{4}$
}

\begin{abstract}
Leg 140 of the Ocean Drilling Program deepened Hole 504B to a total depth of $2000.4 \mathrm{~m}$ below seafloor (mbsf), making it the deepest hole drilled into ocean crust. Site 504, south of the Costa Rica Rift, is considered the most important in-situ reference section for the structure of shallow ocean crust. We present the results of studies of magnetic mineralogy and magnetic properties of Hole 504B upper crustal rocks recovered during Legs 137 and 140. Results from this sample set are consistent with those discussed in Pariso et al. (this volume) from Legs 111, 137, and 140. Coercivity $\left(H_{C}\right)$ ranges from 5.3 to $27.7 \mathrm{mT}$ (mean $12 \mathrm{mT}$ ), coercivity of remanence $\left(H_{C R}\right)$ ranges from 13.3 to $50.6 \mathrm{mT}$ (mean $26 \mathrm{mT}$ ), and the ratio $H_{C R} / H_{C}$ ranges from 1.6 to 3.19 (mean 2.13). Saturation magnetization $\left(J_{S}\right)$ ranges from 0.03 to $5.94 \times 10^{-6} \mathrm{Am}^{2}$, (mean $2.52 \times 10^{-6} \mathrm{Am}^{2}$ ), saturation remanence $\left(J_{R}\right)$ ranges from 0.01 to $0.58 \times 10^{-6} \mathrm{Am}^{2}$ (mean $0.37 \times 10^{-6} \mathrm{Am}^{2}$ ), and the ratio $J_{R} / J_{S}$ ranges from 0.08 to 0.29 (mean 0.16 ), consistent with pseudo-singledomain behavior. Natural remanent magnetization (NRM) intensity ranges from 0.029 to $7.18 \mathrm{~A} / \mathrm{m}$ (mean $2.95 \mathrm{~A} / \mathrm{m}$ ), whereas $\mathrm{RM}_{10}$ intensity varies only from 0.006 to $4.8 \mathrm{~A} / \mathrm{m}$ and has a mean of only $1.02 \mathrm{~A} / \mathrm{m}$. Anhysteretic remanent magnetization (ARM) intensity ranges from 0.04 to $6.0 \mathrm{~A} / \mathrm{m}$, with a mean of $2.46 \mathrm{~A} / \mathrm{m}$, and isothermal remanent magnetization (IRM) intensity ranges from 0.5 to $1683 \mathrm{~A} / \mathrm{m}$, with a mean of $430.7 \mathrm{~A} / \mathrm{m}$. Volume susceptibility ranges from 0.0003 to $0.043 \mathrm{SI}$ (mean $0.011 \mathrm{SI}$ ). In all samples examined, high-temperature oxidation of primary titanomagnetite has produced lamellae or pods of magnetite and ilmenite. Hydrothermal alteration has further altered the minerals in some samples to a mixture of magnetite, ilmenite, titanite, and a high-titanium mineral (either rutile or anatase). Electron microprobe analyses show that magnetite lamellae are enriched in the trivalent oxides $\mathrm{Cr}_{2} \mathrm{O}_{3}$, $\mathrm{Al}_{2} \mathrm{O}_{3}$, and $\mathrm{V}_{2} \mathrm{O}_{5}$, whereas divalent oxides $(\mathrm{MnO}$ and $\mathrm{MgO})$ are concentrated in ilmenite lamellae.
\end{abstract}

\section{INTRODUCTION}

During Leg 140 of the Ocean Drilling Program, Hole 504B was extended to a total depth of $2000.4 \mathrm{~m}$ below seafloor (mbsf), making it the deepest hole ever drilled into ocean crust. Site 504 is located 201 $\mathrm{km}$ south of the Costa Rica Rift, the easternmost arm of the Galapagos Spreading Center (latitude $1^{\circ} 13.611^{\prime} \mathrm{N}$; longitude $83^{\circ} 43.818^{\prime} \mathrm{W}$; water depth $3460 \mathrm{~m}$ ), in 5.9-m.y.-old crust (Fig. 1). Hole 504B provides our most important in-situ reference section for the structure of shallow ocean crust. Leg 140 was the seventh leg of DSDP/ODP to occupy Hole 504B, which was begun during DSDP Leg 69 and subsequently deepened and/or logged during parts of five other legs: Leg 70 (1979), Leg 83 (1981-1982) Leg 92 (1983), Leg 111 (1986), and Leg 137 (1991). These legs provided a wealth of scientific results, much of which is summarized by CRRUST (1982); Cann, Langseth, Honnorez, Von Herzen, White, et al. (1983); Anderson, et al. (1982); Anderson, Honnorez, Becker, et al. (1985); Leinen, Rea, et al. (1986); Becker, Sakai, et al. (1988, 1989); Becker et al. (1989); Alt et al. (1986); Becker, Foss, et al. (1992); and Dick, Erzinger, Stokking, et al., (1992).

We present the results of studies of magnetic mineralogy and magnetic properties of Hole 504B upper crustal rocks drilled during Legs 137 and 140. Pariso et al. (this volume) discuss magnetic petrography in conjunction with magnetic properties, and Allerton, McNeill et al. (this volume) relate structural to magnetic fabrics, and Allerton, Pariso et al. (this volume) address components of natural remanent magnetization.

\footnotetext{
'Erzinger, J., Becker, K., Dick, H.J.B., and Stokking, L.B. (Eds.), 1995. Proc. ODP, Sci. Results, 137/140: College Station, TX (Ocean Drilling Program).

2 Ocean Drilling Program, Texas A\&M University Research Park, 1000 Discovery Drive, College Station, TX 77845-9547, U.S.A.

3 School of Oceanography, University of Washington, Seattle, WA 98195 , U.S.A.

${ }^{4}$ Department of Earth Sciences, University of Oxford, Parks Road, Oxford OX1 3PR. United Kingdom.
}

\section{BACKGROUND}

Understanding the structure, tectonics, mineralogy, and chemical alteration processes in the oceanic crust is one of the most important scientific goals of the Ocean Drilling Program and the primary objective of Leg 140. Knowledge of the nature of the oceanic basement is derived mainly from studies of ophiolite complexes, remote geophysical surveys, and studies made on dredged or cored samples from the ocean floor. Only Hole 504B penetrates through the extrusive pillow lavas into the sheeted dike complex to provide a representative in-situ section of the ocean crust.

Although the magnetic structure of the extrusive rocks of the oceanic crust is well studied, little is known about the magnetic structure of intrusive oceanic rocks or their contribution to marine magnetic anomalies. Studies of rock magnetic properties and the potential contribution to marine magnetic anomalies have been performed on upper crustal rocks drilled during Legs 111 (upper sheeted dike section, Hole 504B; Pariso and Johnson, 1989, 1991) and 118 (gabbros, Atlantis II Fracture Zone, Hole 735B; Kikawa and Pariso, 1991). The potential contribution of the material to a magnetic anomaly is evaluated by the measurement of magnetic susceptibility and remanence characteristics, such as natural remanent magnetization (the sum of all types of remanence acquired by the sample, including any thermal remanence retained by primary phases, chemical remanence acquired by any secondary minerals produced during alteration or weathering, and viscous remanence), stability of remanence, and the Koenigsberger ratio: the ratio of remanent to induced magnetization. Pariso and Johnson (1991) demonstrated that the upper portion of the sheeted dike complex at Hole 504B drilled during Leg 111 may contribute substantially to the magnetic anomaly measured at the sea surface.

The magnetic properties of rocks depend on many variables: the types of magnetic minerals present in the rock (which themselves reflect the initial rock composition and any alteration, thermal or chemical, that the rock has undergone), the concentrations and the grain volumes of the various magnetic minerals in the rock, and the magnetic domain state of those minerals. The predominant magnetic mineral in ocean crustal rocks is titanomagnetite, a spinel that is a solid 


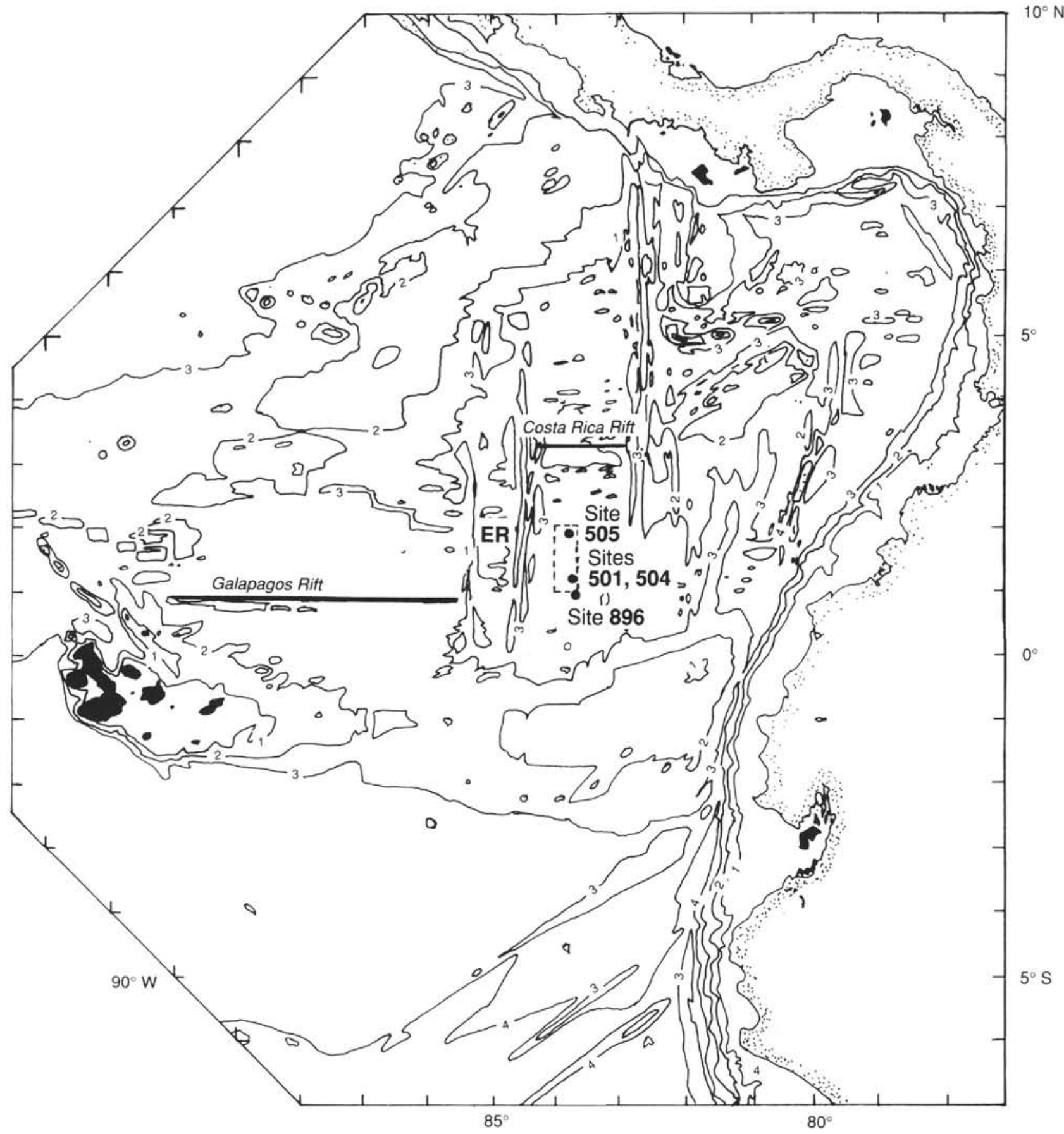

Figure 1. Location of Hole 504B (after Hobart et al., 1985).

solution between iron and titanium, which may also contain aluminum, chromium, magnesium, vanadium, manganese, and nickel. Secondary phases, such as titanomaghemite, ilmenite, magnetite, hematite, and titanite, are produced by thermal and chemical alteration of titanomagnetite. In some cases, secondary phases and alteration textures (i.e., the exsolution of primary titanomagnetite into low-titanium titanomagnetite and high-titanium hemoilmenite; Haggerty, 1976; Smith et al., 1991) can be observed using reflected light microscopy (Ade-Hall et al., 1971; Johnson and Hall, 1978). In other cases, however, the exsolution lamellae are too fine to be observed optically but can be detected by the disagreement between the bulk composition of a grain (determined by electron microprobe analysis) and the Curie temperature (the temperature above which a mineral behaves paramagnetically and cannot retain a magnetic remanence) predicted on the basis of that bulk composition (Evans and Wayman, 1974; Smith and Banerjee, 1986; Smith et al., 1991).

Magnetic minerals are identified and characterized on the basis of reflected and transmitted light microscopy in conjunction with electron microprobe analysis, alternating field demagnetization behavior, anhysteretic and isothermal remanence acquisition, and hysteresis parameters. Alternating field (AF) demagnetization yields the coercivity spectrum, (a property that, assuming the sample contains a single type of magnetic carrier, is itself dependent on the grainvolume spectrum in the rock) and indicates whether the coercivity determined by measurement of hysteresis represents that of the carrier of remanence. Measurement of magnetic hysteresis (the magneti- 
zation behavior exhibited by a sample in the presence of an increasing magnetic field) will determine coercivity, saturation remanence, and saturation magnetization. These parameters, in conjunction with coercivity of remanence (a measurement of the reverse field required to remove saturation isothermal remanence), will then provide constraints on the domain state of the magnetic minerals in the sample (Dunlop, 1969).

\section{LITHOLOGY AND ALTERATION}

The Hole 504B basement section includes $571.5 \mathrm{~m}$ of pillow lavas and minor flows, underlain by a 209 -m transition zone of mixed pillow lavas, thin flows and dikes, and $945.4 \mathrm{~m}$ of sheeted dikes and massive units (Fig. 2). Coring during Leg 140 recovered $47.7 \mathrm{~m}$, of which $11.4 \%$ was aphyric, $18.6 \%$ sparsely phyric, and $70 \%$ moderately phyric plagioclase-pyroxene-olivine diabase, which was divided into 59 lithological units (Dick, Erzinger, Stokking, et al., 1992). The coarsest unit identified has an average grain size of $1.5 \mathrm{~mm}$, but in terms of texture and grain size, it is a diabase and not a gabbro. Phenocrysts include plagioclase, augite, olivine, and $\mathrm{Cr}$-rich augite. The groundmass is dominated by plagioclase, augite, and titanomagnetite. In a few units $\mathrm{Cr}$-spinel is present as inclusions in olivine and plagioclase. Most of the rocks are seriate porphyritic, a texture in which there is a continuous range of grain sizes from the phenocrysts down to the groundmass (Dick, Erzinger, Stokking, et al., 1992).

All of the recovered rocks are mineralogically and chemically altered to some extent and exhibit a pervasive slight "background" alteration (Fig. 2). Locally, more extensively altered zones occur around veins and in centimeter-sized patches. The background alteration is characterized by a $10 \%-20 \%$ replacement of primary minerals by secondary phases. Olivine in most of the rocks is completely altered, and pseudomorphs have been interpreted to reflect multiple stages of alteration, consisting of early talc + magnetite followed by later chlorite or mixed-layer clay formation. Fresh olivine is present in some samples. Clinopyroxene in the rocks is partly replaced by actinolite. Plagioclase is generally only slightly altered to albite and chlorite along fractures and grain boundaries. In Leg 137/140 rocks, centimeter-sized, green to light gray "patches" of alteration make up about $8 \%$ of the core recovered and are similar to those identified on previous legs. Amygdules containing actinolite and chlorite are surrounded by alteration haloes $(2-10.0 \mathrm{~mm}$ wide) where the rock is extensively altered (about $80 \%$ ) to actinolite, chlorite, albite, and titanite (Dick, Erzinger, Stokking, et al., 1992).

The predominant magnetic oxide mineral in Leg 137 and Leg 140 rocks is low-titanium magnetite, which formed as a result of hightemperature (greater than $500^{\circ}-600^{\circ} \mathrm{C}$ ) deuteric oxidation of primary titanomagnetite to magnetite plus ilmenite (Pariso and Johnson, 1991; Pariso et al., this volume). According to Pariso et al. (this volume), titanomagnetite grains from Leg 137/140 rocks have undergone greater high-temperature deuteric oxidation than rocks from the upper sheeted dikes. Leg 137/140 rocks were then hydrothermally altered to varying degrees, which resulted in the replacement of some or all ilmenite lamellae by titanite and/or a high-titanium mineral (anatase or rutile) accompanied by the loss of iron.

\section{METHODS}

Hysteresis behavior of 15 samples was measured using a Princeton Applied Research vibrating sample magnetometer housed in the Paleomagnetics Laboratory at Scripps Institution of Oceanography. Hysteresis measurements are performed by applying an increasing magnetic field to a sample, then reversing the applied field, while continually measuring the magnetization of the sample as it responds to the changing applied field. A plot of applied field vs. sample magnetization results in a loop, the shape of which is determined by the chemical composition, microstructure, and particle orientation of the magnetic material within the sample (Stacey and Banerjee, 1974; Day et al., 1977; Cisowski, 1980). The acquisition of isothermal remanent magnetization (IRM) and the coercivity of remanence $\left(H_{C R}\right)$ were determined using the vibrating sample magnetometer on the samples whose hysteresis behavior was studied.

Intensities of natural remanent magnetization (NRM) of samples were measured on board the JOIDES Resolution and in the Paleomagnetics Laboratory at Texas A\&M University (TAMU), prior to AF demagnetization. On the Resolution, both a Molspin spinner magnetometer and a 2-G Enterprises (Model 760R) pass-through cryogenic rock magnetometer were used. At TAMU, NRM intensities were measured on a three-axis CTF cryogenic magnetometer housed in a shielded room. The magnetic susceptibilities of discrete samples were measured at TAMU using a Bartington Instruments Susceptibility Meter at a frequency of $0.47 \mathrm{kHz}$.

On the ship, an AF demagnetizer (Model 2G600) capable of producing an alternating field up to $20 \mathrm{mT}$ was used on-line with the pass-through cryogenic magnetometer. $\mathrm{AF}$ demagnetization at higher fields was performed using a single-axis Schonstedt Geophysical Specimen Demagnetizer (Model GSD-1) capable of producing alternating fields up to $100 \mathrm{mT}$. At TAMU, samples were $\mathrm{AF}$ demagnetized using Schonstedt Geophysical Specimen Demagnetizer (Model GSD-1). Samples were analyzed using the cryogenic magnetometers between AF steps.

Exposure to strong magnetic fields in the core barrel, in the steel drill string, and on the drill-rig floor imparts a steep negative inclination to cores, particularly those containing low-coercivity material. This spurious magnetization is removed from most samples by AF demagnetization at a peak field of $10 \mathrm{mT}$. Hence, both NRM intensity and intensity remaining after $10-\mathrm{mT}\left(\mathrm{RM}_{10}\right)$ demagnetization are reported.

After AF demagnetization, the acquisition behavior of anhysteretic remanent magnetization (ARM) was studied for a suite of 11 pilot samples. The Schonstedt AF demagnetizer and an anhysteretic magnetizer constructed at TAMU by W. Sager were used to produce the ARM. The alternating field was progressively increased from 0 to about $100 \mathrm{mT}$ in a direct current (DC) bias field of $0.05 \mathrm{mT}$. Acquired remanence was measured between steps using the cryogenic magnetometer. The ARM was then AF demagnetized so the demagnetization behavior could be compared with that of NRM and IRM. A maximum ARM was subsequently imparted to the 27 samples in the study using an alternating field of $100 \mathrm{mT}$ and a DC bias field of $0.05 \mathrm{mT}$.

An IRM was applied at a saturating field of about $1.0 \mathrm{~T}$ to all samples in the study using an ASC, Inc., impulse magnetizer (Model IM-10) and measured using the DIGICO spinner magnetometer at the University of Rhode Island. Eleven pilot samples were given an IRM at $1.0 \mathrm{~T}$ and $\mathrm{AF}$ demagnetized so the demagnetization of IRM could be compared with that of NRM and ARM.

After all magnetic analyses were performed, polished thin sections were made from 15 representative samples. Electron microprobe analyses were performed to determine the chemical composition (major and trace elements) of the opaque minerals. Opaque minerals were analyzed using a Cameca SX-50 automated electron microprobe in the TAMU Geology Department, using a finely focused $(\approx 1 \mu \mathrm{m})$, nonrastered, spot-fixed electron beam. During analysis, the beam current was $30 \mathrm{nA}$ at $15 \mathrm{kev}$. For ilmenite and magnetite analyses, $\mathrm{Si}$ and $\mathrm{Ca}$ were each counted for $10 \mathrm{~s}$; $\mathrm{Ti}$ and $\mathrm{Fe}$ were each counted for $20 \mathrm{~s} ; \mathrm{V}, \mathrm{Ni}$, and $\mathrm{Zn}$ were each counted for $30 \mathrm{~s} ; \mathrm{Mn}$ and $\mathrm{Cr}$ were each counted for $40 \mathrm{~s} ; \mathrm{Mg}$ was counted for $100 \mathrm{~s}$; and $\mathrm{Al}$ was counted for $110 \mathrm{~s}$. For the titanite analyses, $\mathrm{Ca}$ and $\mathrm{Ti}$ were each counted for $20 \mathrm{~s}, \mathrm{Mn}$ and Fe were each counted for $60 \mathrm{~s}$, and $\mathrm{Mg}$ and $\mathrm{Si}$ were each counted for $80 \mathrm{~s}$. Natural mineral standards used were diopside, spinel, $\mathrm{FeTiO}_{3}$, chromite, ilmenite, spessartine, and gahnite. Metal standards used were nickel and vanadium. Ferric/ferrous calculations were performed using the Cameca program, which uses the Deer, Howie, and Zussman (1962) formulas. 


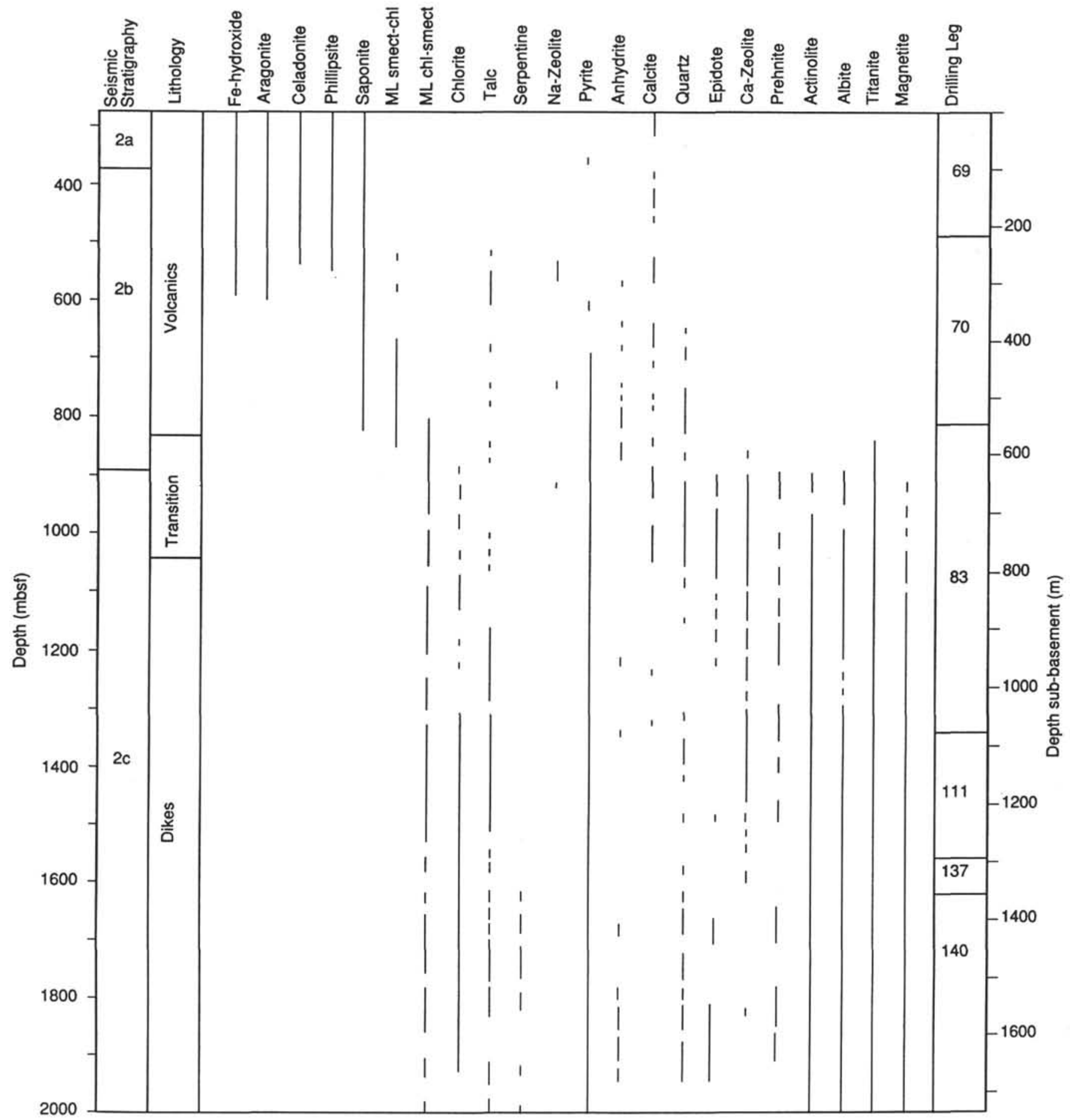

Figure 2. Distribution of secondary mineralogy with depth in Hole 504B. From Alt et al., (1986), Becker, Sakai, et al., (1989).

\section{RESULTS}

Pariso et al. (this volume) present the magnetic properties and petrography of magnetite, ilmenite, and titanite. The causes of variability in the rock-magnetic data are discussed in Pariso et al. (this volume) and reflect variability in alteration. Detailed discussion of these results, in addition to results of analyses of additional samples from Hole 504B collected during Leg 148, will be presented in the Leg 148 Scientific Results volume.

Figure 3 illustrates the hysteresis behavior of representative samples: a relatively unaltered moderately plagioclase-olivine-clinopy- roxene phyric diabase (Sample 140-504B-191R-1, 23-25 cm), an alteration halo in a moderately olivine-plagioclase-clinopyroxene phyric diabase (Sample 140-504B-202R-1, 56-58 cm), and a relatively unaltered highly clinopyroxene-olivine-plagioclase phyric diabase (Sample 140-504B-227R-1,97-99 cm). Figure 4 illustrates the IRM acquisition behavior of those samples. Table 1 summarizes the hysteresis parameters of the samples studied. In this sample set, coercivity ranges from 5.3 to $27.7 \mathrm{mT}$ (mean $12 \mathrm{mT}$ ), coercivity of remanence ranges from 13.3 to $50.6 \mathrm{mT}$ (mean $26 \mathrm{mT}$ ), the ratio $H_{C R} / H_{C}$ ranges from 1.6 to 3.19 (mean 2.13). Saturation magnetization $\left(J_{S}\right)$ ranges from 0.03 to $5.94 \times 10^{-6} \mathrm{Am}^{2}$, (mean $2.52 \times 10^{-6} \mathrm{Am}^{2}$ ), saturation 


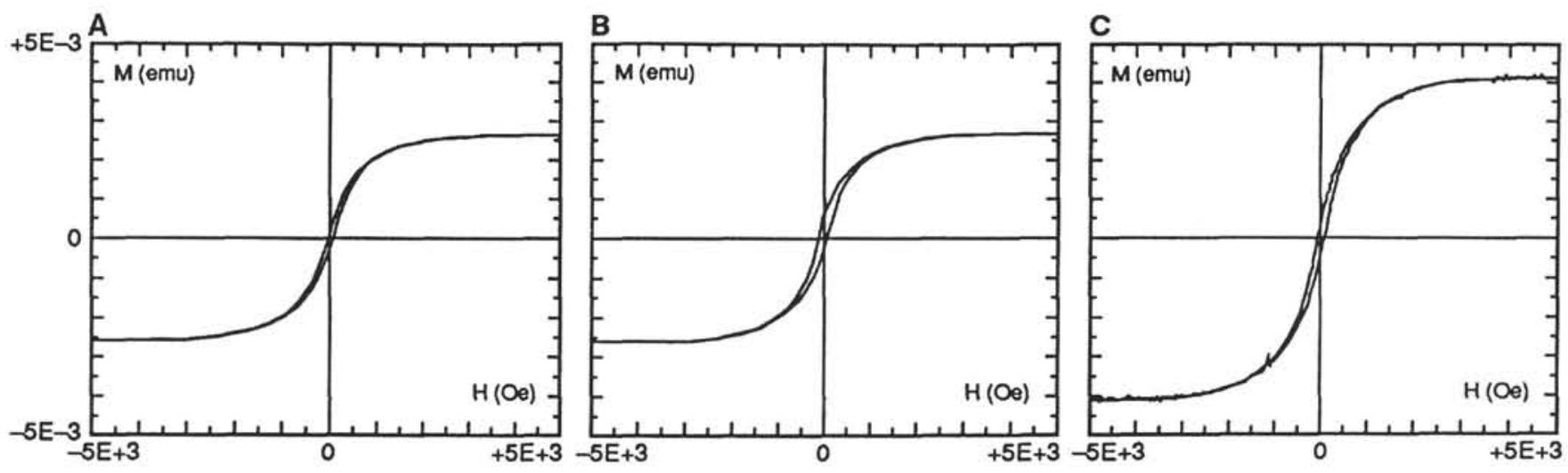

Figure 3. Hysteresis loops. A. Sample 140-504B-191R-1, $23 \mathrm{~cm}$. B. Sample 140-504B-202R-1, $56 \mathrm{~cm}$. C. Sample 140-504B-227R-1, $97 \mathrm{~cm}$.

A

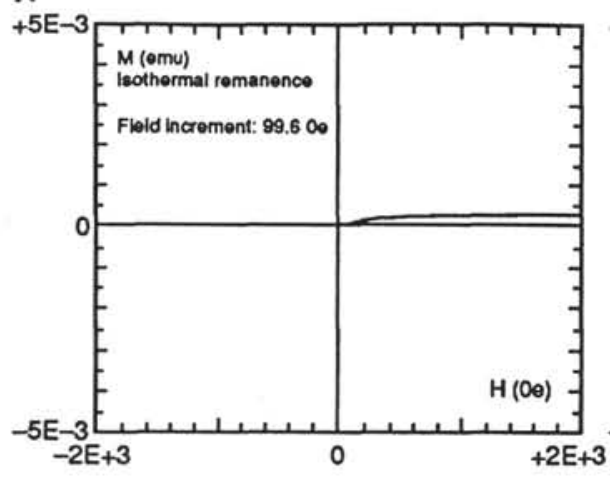

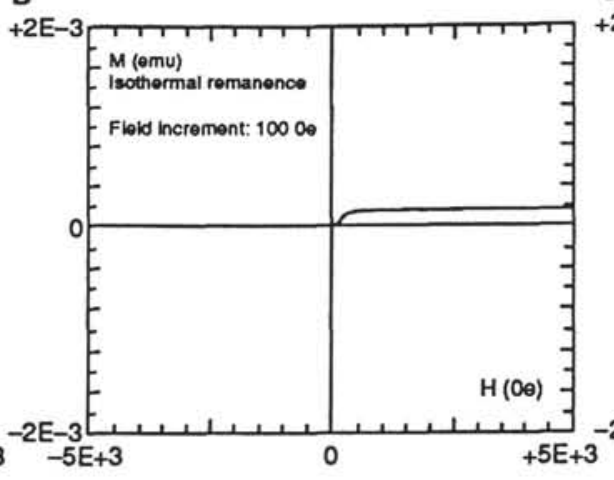

C

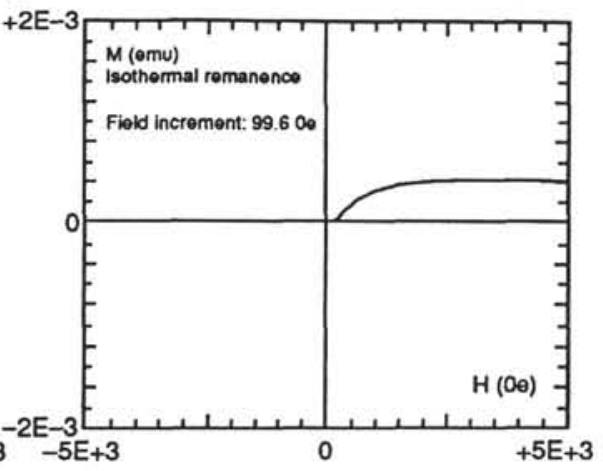

Figure 4. IRM acquisition curves. A. Sample 140-504B-191R-1, $23 \mathrm{~cm}$. B. Sample 140-504B-202R-1, $56 \mathrm{~cm}$. C. Sample 140-504B-227R-1, $97 \mathrm{~cm}$.

Table 1. Hysteresis data, Leg 137/140.

\begin{tabular}{|c|c|c|c|c|c|c|c|c|}
\hline Sample & $\begin{array}{l}\text { Depth } \\
\text { (mbsf) }\end{array}$ & $\begin{array}{c}\mathrm{H}_{C} \\
(\mathrm{mT})\end{array}$ & $\begin{array}{l}H_{C R} \\
(\mathrm{mT})\end{array}$ & $H_{C N} / H_{C}$ & $\begin{array}{c}J \mathrm{~s} \\
\left(10^{-6} \mathrm{Am}^{2}\right)\end{array}$ & $\begin{array}{c}J_{R} \\
\left(10^{-6} \mathrm{Am}^{2}\right)\end{array}$ & $J_{R} / J_{S}$ & $\begin{array}{l}H_{S A T} \\
(\mathrm{mT})\end{array}$ \\
\hline $\begin{array}{l}137-504 \mathrm{~B}- \\
180 \mathrm{M}-2,96\end{array}$ & 1620.53 & 13.8 & 22.1 & 1.6 & 9.56 & 2 & 0.21 & 500 \\
\hline $\begin{array}{l}\text { 140-504B- } \\
189 \mathrm{R}-1,96 \\
191 \mathrm{R}-1,23 \\
193 \mathrm{R}-1,48 \\
200 \mathrm{R}-2,140 \\
202 \mathrm{R}-1,56 \\
204 \mathrm{R}-1,8 \\
206 \mathrm{R}-1,19 \\
208 \mathrm{R}-2,103 \\
209 \mathrm{R}-2,9 \\
214 \mathrm{R}-2,130 \\
221 \mathrm{R}-1,44 \\
222 \mathrm{R}-1,37 \\
227 \mathrm{R}-1,97 \\
236 \mathrm{R}-1,19\end{array}$ & $\begin{array}{l}1651.96 \\
1661.63 \\
1674.98 \\
1731.5 \\
1747.76 \\
1756.58 \\
1760.89 \\
1780.48 \\
1789.09 \\
1821.4 \\
1875.04 \\
1884.97 \\
1925.47 \\
1980.89 \\
\text { Max. } \\
\text { Min. } \\
\text { Mean }\end{array}$ & $\begin{array}{l}5.4 \\
5.3 \\
27.7 \\
9.7 \\
8.7 \\
9.1 \\
15.6 \\
9.2 \\
9.1 \\
17.8 \\
9.4 \\
15 \\
7.7 \\
21.5 \\
27.7 \\
5.3 \\
12.3\end{array}$ & $\begin{array}{l}13.3 \\
13.5 \\
50.6 \\
17.4 \\
16.4 \\
29 \\
38.5 \\
17 \\
16.2 \\
40.7 \\
18.4 \\
33 \\
16.1 \\
43.5 \\
50.6 \\
13.3 \\
25.7\end{array}$ & $\begin{array}{l}2.49 \\
2.54 \\
1.83 \\
1.79 \\
1.89 \\
3.19 \\
2.47 \\
1.85 \\
1.77 \\
2.29 \\
1.96 \\
2.2 \\
2.09 \\
2.02 \\
3.19 \\
1.6 \\
2.132\end{array}$ & $\begin{array}{l}5.94 \\
2.61 \\
0.071 \\
3.95 \\
1.06 \\
0.54 \\
0.04 \\
3.67 \\
2.08 \\
0.03 \\
3.04 \\
1.05 \\
4.09 \\
0.07 \\
5.94 \\
0.03 \\
2.52\end{array}$ & $\begin{array}{l}0.47 \\
0.23 \\
0.03 \\
0.58 \\
0.17 \\
0.05 \\
0.01 \\
0.54 \\
0.34 \\
0.004 \\
0.45 \\
0.18 \\
0.47 \\
0.02 \\
0.58 \\
0.004 \\
0.37\end{array}$ & $\begin{array}{l}0.08 \\
0.09 \\
0.29 \\
0.15 \\
0.16 \\
0.09 \\
0.21 \\
0.15 \\
0.17 \\
0.16 \\
0.15 \\
0.17 \\
0.12 \\
0.23 \\
0.29 \\
0.08 \\
0.162\end{array}$ & $\begin{array}{l}200 \\
200 \\
500 \\
500 \\
500 \\
200 \\
500 \\
500 \\
500 \\
500 \\
500 \\
500 \\
500 \\
200 \\
500 \\
200 \\
420\end{array}$ \\
\hline
\end{tabular}

Note: Abbreviations are defined in the text.

remanence $\left(J_{R}\right)$ ranges from 0.01 to $0.58 \times 10^{-6} \mathrm{Am}^{2}$ (mean $0.37 \times$ $10^{-6} \mathrm{Am}^{2}$ ), and the ratio $J_{R} / J_{S}$ ranges from 0.08 to 0.29 (mean 0.16 ).

Rock magnetic data from all samples in the study are presented in Table 2. NRM intensity ranges from 0.029 to $7.18 \mathrm{~A} / \mathrm{m}$ (mean 2.95 $\mathrm{A} / \mathrm{m}$ ), whereas $\mathrm{RM}_{10}$ intensity varies only from 0.006 to $4.8 \mathrm{~A} / \mathrm{m}$ and has a mean of only $1.02 \mathrm{~A} / \mathrm{m}$. ARM intensity ranges from 0.04 to 6.0 $\mathrm{A} / \mathrm{m}$, with a mean of $2.46 \mathrm{~A} / \mathrm{m}$, and IRM intensity ranges from 0.5 to $1683 \mathrm{~A} / \mathrm{m}$, with a mean of $430.7 \mathrm{~A} / \mathrm{m}$. Volume susceptibility ranges
Table 2. Rock-magnetic data.

\begin{tabular}{|c|c|c|c|c|c|c|c|c|}
\hline Sample & $\begin{array}{l}\text { Depth } \\
\text { (mbsf) }\end{array}$ & $\begin{array}{l}\text { NRM } \\
(\mathrm{A} / \mathrm{m})\end{array}$ & $\begin{array}{l}\mathrm{RM}_{10} \\
(\mathrm{~A} / \mathrm{m})\end{array}$ & $\begin{array}{l}\text { ARM } \\
(\mathrm{A} / \mathrm{m})\end{array}$ & $\begin{array}{l}\text { IRM } \\
(\mathrm{A} / \mathrm{m})\end{array}$ & K & Unit & Lith. \\
\hline $\begin{array}{l}137-504 \mathrm{~B}- \\
180 \mathrm{M}-2,96\end{array}$ & 1620.53 & 1.06 & 1.14 & 6 & 1683.02 & 0.043 & 205 & $\mathrm{PCO}$ \\
\hline \multicolumn{9}{|l|}{ 140-504B- } \\
\hline $189 \mathrm{R}-2,39$ & 1652.89 & 2.6 & 0.426 & 1.88 & 194.66 & 0.007 & 218 & POC \\
\hline 190R-1, 95 & 1656.05 & 1.03 & 0.232 & 0.43 & 71.99 & 0.005 & 218 & POC \\
\hline $191 R-1,25$ & 1661.63 & 3.88 & 0.74 & 3.96 & 608.17 & 0.027 & 218 & POC \\
\hline $193 \mathrm{R}-1,48$ & 1674.98 & 0.029 & 0.006 & 0.04 & 0.53 & 0.0003 & 220 & POC \\
\hline $197 \mathrm{R}-1,131$ & 1704.11 & 5.82 & 1.24 & 4.66 & 707.66 & 0.028 & 223 & POC \\
\hline 200R-1, 128 & 1729.88 & 4.8 & 4.8 & 3.45 & 531.75 & 0.016 & 227 & POC \\
\hline $200 \mathrm{R}-2,140$ & 1731.5 & 4.21 & 4.21 & 3.84 & 618.45 & 0.011 & 227 & POC \\
\hline $200 \mathrm{R}-3,55$ & 1732.15 & 5.37 & 2.02 & 3.86 & 568.96 & 0.014 & 227 & POC \\
\hline $202 \mathrm{R}-1,56$ & 1747.76 & 1.11 & 0.43 & 0.88 & 47.87 & 0.002 & 230 & OPC \\
\hline $204 \mathrm{R}-1,8$ & 1756.58 & 0.73 & 0.43 & 1.68 & 161.22 & 0.004 & 232 & $\mathrm{PCO}$ \\
\hline 206R-1, 19 & 1760.89 & 2.36 & 0.55 & 2.55 & 533.70 & 0.007 & 235 & COP \\
\hline 208R-2, 103 & 1780.48 & 3.54 & 1.16 & 2.83 & 574.36 & 0.011 & 239 & OPC \\
\hline 209R-2, 9 & 1789.09 & 0.087 & 0.022 & 0.14 & 3.54 & 0.0004 & 240 & OPC \\
\hline $209 \mathrm{R}-2,16$ & 1789.1 & 0.71 & 0.33 & 0.53 & 84.27 & 0.001 & 240 & OPC \\
\hline $210 \mathrm{R}-1,91$ & 1795.81 & 6.51 & 2.06 & 3.21 & 510.71 & 0.010 & 241 & POC \\
\hline $211 \mathrm{R}-1,129$ & 1799.79 & 7.18 & 1.25 & 4.92 & 1260.65 & 0.018 & 241 & POC \\
\hline $214 \mathrm{R}-1,132$ & 1819.92 & 6.89 & 1.14 & 5.48 & 1337.54 & 0.025 & 244 & POC \\
\hline $214 \mathrm{R}-2,130$ & 1821.4 & 6.2 & 1.01 & 0.15 & 2.21 & 0.0003 & 244 & POC \\
\hline $221 \mathrm{R}-1,44$ & 1875.04 & 3.49 & 1.04 & 3.59 & 401.94 & 0.011 & 254 & COP \\
\hline $222 \mathrm{R}-1,37$ & 1884.97 & 0.82 & 0.53 & 1.81 & 173.30 & 0.004 & 254 & COP \\
\hline 225R-2, 37 & 1914.07 & 3.17 & 1.16 & 2.91 & 418.78 & 0.020 & 260 & COP \\
\hline $226 \mathrm{R}-2,103$ & 1922.53 & 0.11 & 0.05 & 0.24 & 5.43 & 0.001 & 260 & COP \\
\hline $227 \mathrm{R}-1,97$ & 1925.47 & 4.8 & 1.16 & 3.71 & 677.28 & 0.017 & 260 & COP \\
\hline $227 \mathrm{R}-1,101$ & 1925.51 & 0.19 & 0.08 & 0.29 & 12.43 & 0.001 & 260 & COP \\
\hline \multirow[t]{4}{*}{$236 \mathrm{R}-1,19$} & 1980.89 & 0.04 & 0.03 & 0.19 & 2.40 & 0.001 & 269 & POC \\
\hline & Max. & 7.18 & 4.80 & 6.00 & 1683.02 & 0.04 & & \\
\hline & Min. & 0.03 & 0.01 & 0.04 & 0.53 & 0.00 & & \\
\hline & Mean & 2.95 & 1.02 & 2.46 & 430.70 & 0.01 & & \\
\hline
\end{tabular}

Notes: Lith. $=$ lithology; $\mathrm{PCO}=$ plagioclase-clinopyroxene-olivine phyric diabase; $\mathrm{POC}=$ plagioclase-olivine-clinopyroxene diabase; $\mathrm{OPC}=$ olivine-plagioclase-clinopyroxene phyric diabase; $\mathrm{COP}=$ clinopyroxene-olivine-pyroxene phyric diabase. Other abbreviations are defined in the text. 


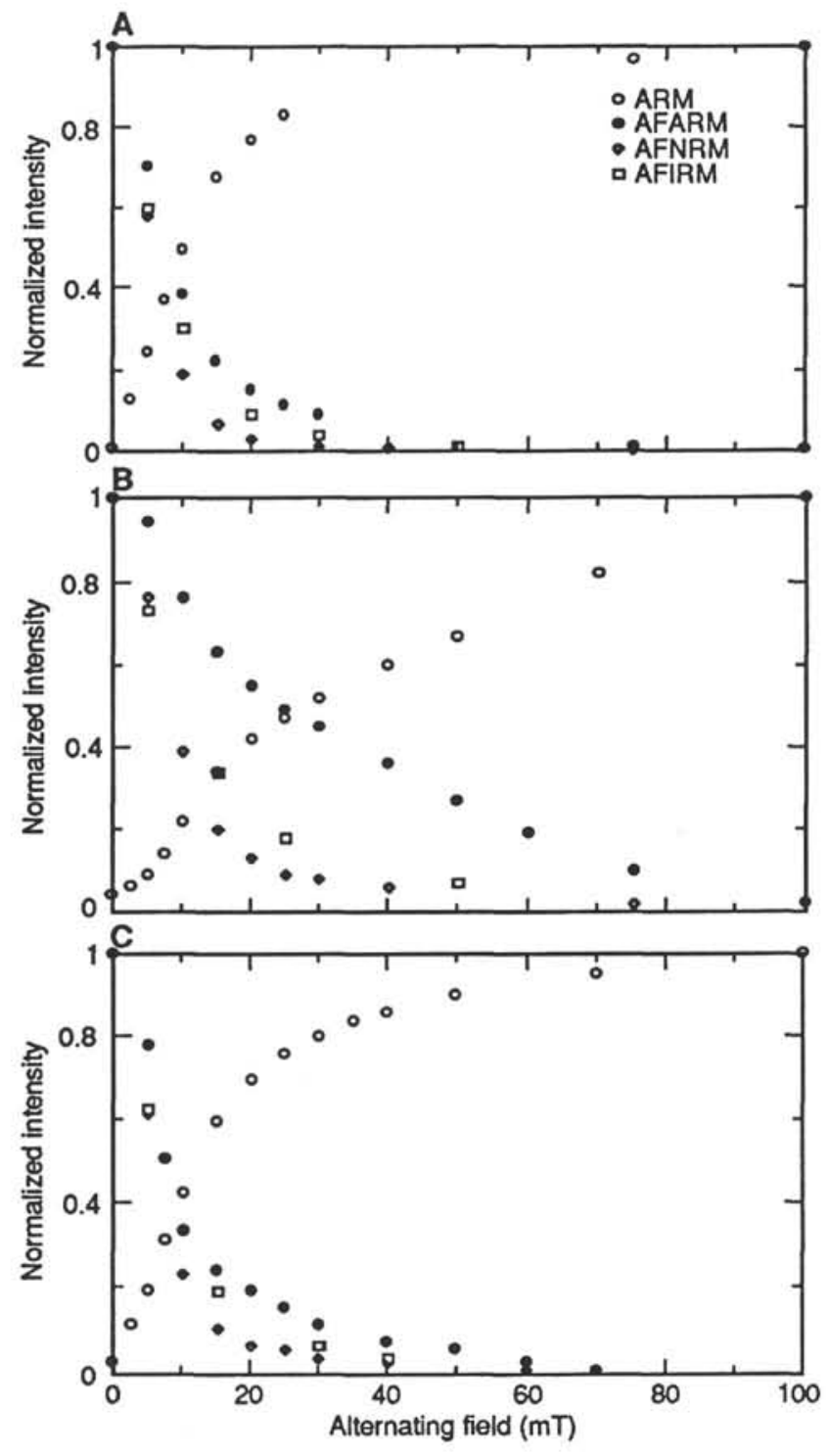

Figure 5. ARM acquisition curves (open circles), AF demagnetization of NRM (diamonds), ARM (filled circles), and IRM (squares). A. Sample 140-504B$191 \mathrm{R}-1,23 \mathrm{~cm}$. B. Sample 140-504B-202R-1, $56 \mathrm{~cm}$. C. Sample 140-504B$227 \mathrm{R}-1,97 \mathrm{~cm}$.

from $0.0003 \mathrm{SI}$ to $0.043 \mathrm{SI}$ (mean $0.011 \mathrm{SI}$ ). Figure 5 illustrates representative ARM acquisition curves and AF demagnetization behavior of NRM, IRM, and ARM for Samples 140-504B-191R-1, 23-25 cm, 140-504B-202R-1, 56-58 cm, and 140-504B-227R-1, 97-99 cm.

Major- and trace-element geochemical analyses are presented in Table 3. Back-scattered electron images of two grains from Sample 140-504B-191R-1, 23-25 cm, and one grain from Sample 140-504B$227 \mathrm{R}-1,97-99 \mathrm{~cm}$, are illustrated in Figure 6. In all samples examined, high-temperature oxidation of primary titanomagnetite has produced lamellae or pods of magnetite and ilmenite. Hydrothermal alteration has further altered the minerals to a mixture of magnetite, ilmenite, titanite, and a high-titanium mineral (either rutile or anatase), as discussed in Pariso et al. (this volume). Table 3 shows that magnetite lamellae tend to be enriched in trivalent elements: $\mathrm{Cr}_{2} \mathrm{O}_{3}$ averages $0.12 \mathrm{wt} \%$ in magnetite relative to $0.02 \mathrm{wt} \%$ in ilmenite, $\mathrm{Al}_{2} \mathrm{O}_{3}$ averages $0.91 \mathrm{wt} \%$ in magnetite and only $0.16 \mathrm{wt} \%$ in ilmenite, and $\mathrm{V}_{2} \mathrm{O}_{5}$ averages $1.36 \mathrm{wt} \%$ in magnetite and $0.50 \mathrm{wt} \%$ in ilmenite. Divalent elements are partitioned into ilmenite lamellae: $\mathrm{MnO}$ aver- ages $2.96 \mathrm{wt} \%$ in ilmenite and $0.06 \mathrm{wt} \%$ in magnetite, and $\mathrm{MgO}$ averages $0.14 \mathrm{wt} \%$ in ilmenite and only $0.01 \mathrm{wt} \%$ in magnetite.

\section{DISCUSSION AND CONCLUSIONS}

The predominant magnetic oxide mineral in Leg 137 and Leg 140 rocks is low-titanium magnetite, produced during high-temperature (greater than $500^{\circ}-600^{\circ} \mathrm{C}$ ) deuteric oxidation of primary titanomagnetite to magnetite plus ilmenite (Pariso and Johnson, 1991; Pariso et al., this volume). Subsequently, Leg 137/140 rocks were hydrothermally altered to varying extents: some or all ilmenite lamellae were replaced by titanite and/or a high-titanium mineral (anatase or rutile) and some iron was lost.

The ranges of NRM intensity and magnetic susceptibility measured in this suite of samples are consistent with those reported in Pariso et al. (this volume), which reflect a general slight increase in both properties with depth in the sheeted dike section. The shapes of ARM and IRM acquisition curves are consistent with the predominant magnetic carrier being low-titanium magnetite. The mean ratio $J_{R} / J_{S}$ is 0.16 , consistent with pseudo-single-domain behavior, and close to the mean value reported for the entire sheeted dike section ( 0.19 ; Pariso et al., this volume). Magnetic remanence (natural and laboratory-induced) and magnetic susceptibility reflect the concentration of magnetic carriers in the rock. Samples whose magnetic intensity is low also have low magnetic susceptibility (Table 2) and low saturation magnetization (Table 1), as discussed in Pariso et al. (this volume) and implying that the low remanence and susceptibility values reflect a decrease in the amount of magnetite. This variation in concentration of magnetite in turn reflects hydrothermal alteration, which causes loss of iron and replacement of ilmenite by anatase and/or rutile (Pariso and Johnson, 1992; Pariso et al., this volume). As observed by Pariso and Johnson (1992) and Pariso et al. (this volume), samples whose magnetic intensity and susceptibility are low show evidence of high degrees of hydrothermal alteration, whereas samples whose magnetic intensity and susceptibility are moderate to high are less altered. Thus, variability in the amount of magnetizable material produced by differing degrees of hydrothermal alteration of the samples results in the wide variation in rock magnetic properties observed in this suite of samples.

Deer, Howie, and Zussman (1962) and Haggerty (1976) report the partitioning of divalent ions ( $\mathrm{Mn}$ and $\mathrm{Mg}$ ) into ilmenite and trivalent ions $(\mathrm{Cr}, \mathrm{Al}, \mathrm{V})$ into magnetite when the two minerals are associated. This distribution was observed in altered and unaltered magnetite and in primary and secondary ilmenite from Hole 504B extrusives and upper sheeted dikes drilled during ODP Leg 83 (Kempton et al., 1985): $\mathrm{Al}_{2} \mathrm{O}_{3}$ and $\mathrm{Cr}_{2} \mathrm{O}_{3}$ concentrations are higher in both altered and unaltered magnetite than in ilmenite, whereas $\mathrm{MgO}$ and $\mathrm{MnO}$ are higher in both primary and secondary ilmenite than in associated magnetite or titanomagnetite. Vanadium concentrations were not reported. Thus, the variations in major and trace elements observed in the lower sheeted dikes drilled during Legs 137 and 140 are consistent with trends observed in magnetite-ilmenite associations in general, as well as in the extrusives and upper sheeted dikes from Hole 504B. Work in progress involves correlating rock magnetic properties and the degree of oxide alteration with ratios of trivalent trace elements to trivalent iron and with ratios of divalent trace elements to divalent iron.

\section{ACKNOWLEDGMENTS}

We thank J. Aguiar for assistance with data processing. We thank L. Tauxe for permitting us to use the vibrating sample magnetometer in the Paleomagnetics Laboratory at the Scripps Institution of Oceanography, and we thank J. King for allowing us to use the spinner magnetometer at the University of Rhode Island. We are grateful to R. Guillemette for his guidance and assistance with the electron microprobe. This research was supported by a grant to L.S. from the U.S. Science Support Program of the Joint Oceanographic Institutions, Inc. 
Table 3. Major- and trace-element microprobe analyses.

\begin{tabular}{|c|c|c|c|c|c|c|c|c|c|c|c|c|c|}
\hline Analysis & $\begin{array}{c}\mathrm{SiO}_{2} \\
(\mathrm{wt} \%)\end{array}$ & $\begin{array}{c}\mathrm{MgO} \\
\text { (wt\%) }\end{array}$ & $\begin{array}{l}\mathrm{Al}_{2} \mathrm{O}_{3} \\
\text { (wt } \% \text { ) }\end{array}$ & $\begin{array}{c}\mathrm{TiO}_{2} \\
(\mathrm{wt} \%)\end{array}$ & $\begin{array}{l}\mathrm{Cr}_{2} \mathrm{O}_{3} \\
(\mathrm{wt} \%)\end{array}$ & $\begin{array}{c}\mathrm{CaO} \\
(\mathrm{wt} \%)\end{array}$ & $\begin{array}{c}\mathrm{MnO} \\
\text { (wt\%) }\end{array}$ & $\begin{array}{l}\mathrm{V}_{2} \mathrm{O}_{5} \\
\text { (wt\%) }\end{array}$ & $\begin{array}{c}\mathrm{FeO} \\
(\mathrm{wt} \%)\end{array}$ & $\begin{array}{c}\mathrm{NiO} \\
(\mathrm{wt} \%)\end{array}$ & $\begin{array}{c}\mathrm{ZnO} \\
(\mathrm{wt} \%)\end{array}$ & $\begin{array}{l}\mathrm{Fe}_{2} \mathrm{O}_{3} \\
\text { (wt \%) }\end{array}$ & $\begin{array}{l}\text { Totals } \\
\text { (wt\%) }\end{array}$ \\
\hline \multicolumn{14}{|l|}{ 140-504B- } \\
\hline 191R-1, 25-b1-magn-1 & 0.19 & 0.00 & 2.30 & 2.85 & 0.14 & 0.48 & 0.01 & 1.48 & 4.22 & 0.07 & 0.01 & 93.25 & 105.00 \\
\hline 191R-1, 25-a3-magn-1 & 0.70 & 0.00 & 0.80 & 3.58 & 0.08 & 0.88 & 0.06 & 1.16 & 34.45 & 0.03 & 0.16 & 61.06 & 102.96 \\
\hline 19IR-1, 25-a.3-magn-2 & 0.11 & 0.00 & 1.06 & 1.84 & 0.11 & 0.33 & 0.05 & 1.37 & 32.94 & 0.00 & 0.05 & 64.22 & 102.08 \\
\hline 200R-3, 55-b1-magn-1 & 0.60 & 0.07 & 1.04 & 3.31 & 0.15 & 0.46 & 0.14 & 1.54 & 33.89 & 0.04 & 0.07 & 60.90 & 102.21 \\
\hline 213R-1, 75-a2-magn- 1 & 0.17 & 0.00 & 0.82 & 1.51 & 0.14 & 0.43 & 0.04 & 1.48 & 32.44 & 0.02 & 0.04 & 64.76 & 101.85 \\
\hline 213R-1, 75-a2-magn-2 & 0.66 & 0.00 & 0.13 & 2.35 & 0.11 & 1.26 & 0.09 & 1.25 & 32.37 & 0.02 & 0.04 & & 100.76 \\
\hline 213R-1, 75-a1-magn-1 & 0.12 & 0.00 & 1.43 & 1.70 & 0.19 & 0.37 & 0.04 & 2.07 & 32.46 & 0.00 & 0.05 & 3.02 & 101.45 \\
\hline 213R-1, 75-a1-magn-2 & 0.32 & 0.00 & 0.62 & 1.78 & 0.12 & 0.82 & 0.03 & 1.50 & 32.52 & 0.02 & 0.09 & 64.18 & 102.00 \\
\hline 227R-1, 97-b-magn-1 & 0.47 & 0.01 & 0.11 & 3.59 & 0.13 & 0.60 & 0.02 & 1.40 & 3.32 & 0.00 & 0.00 & 96.19 & 105.84 \\
\hline 227R-1, 97-a-magn-1 & 0.11 & 0.00 & 0.34 & 5.10 & 0.07 & 0.08 & 0.05 & 1.04 & 4.79 & 0.02 & 0.05 & 93.89 & 105.54 \\
\hline 2271 & 0.15 & 0.02 & 2.59 & 5.58 & 0.17 & 0.1 & 13 & 1.68 & 6.76 & 0.02 & 9 & 87.19 & 104.60 \\
\hline $227 \mathrm{R}-1,97-\mathrm{d}$ & 0.12 & 0.00 & 0.07 & 0.62 & 0.07 & 0.23 & 0.02 & 0.73 & 31.61 & 0.02 & 0.00 & 67.67 & 101.16 \\
\hline $227 \mathrm{R}-1,97-\mathrm{d}$-magn- 2 & 0.12 & 0.00 & 0.49 & 4.25 & 0.08 & 0.12 & 0.05 & 0.92 & 35.20 & 0.03 & 0.00 & 60.54 & 101.80 \\
\hline Maximum & 0.70 & 0.07 & 2.59 & 5.58 & 0.19 & & 14 & 2.07 & 35.20 & 0.07 & 0.19 & 96.19 & 105.84 \\
\hline Minim & 0.11 & 0.00 & 0.07 & 0.62 & 0.07 & & & 0.73 & 3.32 & 0.00 & 0.00 & 60.54 & 100.76 \\
\hline Mean & 0.30 & 0.01 & 0.91 & 2.93 & 0.12 & 0.48 & 0.06 & 1.36 & 24.38 & 0.02 & 0.06 & 72.26 & 102 \\
\hline 19 & 0 & & 0.37 & 45.38 & 0.0 & & 3.60 & 37 & & 0 & 0.0 & 5.45 & 98.20 \\
\hline ne-1 & 0.41 & 0.00 & 0.07 & 5 & 0. & & 0 & 1 & 9 & 0 & 0 & 0.00 & 98.69 \\
\hline ilme-1 & 0.33 & 0.06 & 0.04 & 48.91 & 0.00 & & & 1 & & 0.00 & & 5.85 & 99.72 \\
\hline $200 R$ & 0.48 & 0.05 & 0.04 & 48.74 & 0.00 & 0.7 & 2.0 & 9 & 41 & 0.00 & 0.01 & 5.96 & 100.01 \\
\hline 200R-3, 55-b1-ilme-1 & 0.05 & 0.05 & 0.03 & 49.06 & 0.01 & 0.17 & 2.09 & 0.33 & 47.54 & 0.00 & 0.03 & 0.00 & 99.36 \\
\hline 202R-1, 56-a-ilme-1 & 0.06 & 0.03 & 0.03 & 49.30 & 0.03 & 0.30 & 5.67 & 0.36 & 38.58 & 0.00 & 0.00 & 5.13 & 99.49 \\
\hline 202R-1, 56-a-ilme-2 & 0.16 & 0.04 & 0.08 & 48.82 & 0.02 & 0.62 & 5.05 & 0.36 & 38.79 & 0.00 & 0. & 5.19 & 99.13 \\
\hline$e-1$ & 3.18 & 0 & 0.16 & 44.03 & 0.04 & & & 0 & 35 & 0.03 & 0.07 & 12.16 & 100.77 \\
\hline -a4-ilme-1 & 0.08 & 0.0 & 0.02 & 45.66 & 0.0 & & .80 & 0.55 & 38 & 0.00 & 0.01 & 11.86 & 99.67 \\
\hline 213R-1, 75-a4-ilme-2 & 0.05 & 0.05 & 0.04 & 45.84 & 0.00 & 0.3 & 2.81 & 0.45 & 38.31 & 0.00 & 0.00 & 11.74 & 99.61 \\
\hline 213R-1, 75-al-ilme-1 & 0.08 & 0.03 & 0.03 & 45.51 & 0.04 & 0. & 3.31 & 0.53 & 37.56 & 0.02 & 0.10 & 11.93 & 99.63 \\
\hline -ilme-2 & 0.06 & 0.1 & 0.04 & 45.69 & 0.1 & & & 7 & 38 & 0 . & 0. & 47 & 99.06 \\
\hline$e-1$ & 3.90 & 1.1 & 1.37 & 33.51 & 0.0 & 2. & 3 & 0.69 & 26.40 & 0.02 & 0.06 & 25.25 & 97.18 \\
\hline 227R-1, 97-a-ilme-1 & 0.15 & 0.0 & 0.16 & 44.89 & 0.1 & & & & 37 & 0.03 & 0.0 & 15.07 & 101.55 \\
\hline 227R-1, 97-a-ilme-2 & 0.12 & 0.08 & 0.13 & 48.71 & 0.0 & 0.0 & 3.8 & 0.63 & 39.90 & 0.01 & 0.05 & 6.17 & 99.74 \\
\hline 227R-1,97-a-ilme-3 & 0.17 & 0.07 & 0.05 & 49.34 & 0.03 & 0.2 & 3.51 & 0.62 & 40.75 & 0.03 & 0.07 & 5.22 & 100.08 \\
\hline me-1 & 1.79 & 0.1 & 0.21 & 51.03 & 0.0 & & 3. & 0.73 & 40 & 0 . & 0. & 0.00 & 99.97 \\
\hline $227 \mathrm{~F}$ & 0.09 & 0 & 0.10 & 45.66 & 0.0 & 0 . & 2 & 0.62 & 38 & 0.00 & 0.04 & 11.23 & 99.05 \\
\hline 227R-1, 97-d-ilme-2 & 0.08 & 0.0 & 0.09 & 48.96 & 0.0 & & 2. & 0.56 & 41.49 & 0.00 & 0.03 & 6.59 & 100.51 \\
\hline Maximum & 3.90 & 1.12 & 1.37 & 92.85 & 0.06 & 2.9 & 5.67 & 0.73 & 47.54 & 0.03 & 0.10 & 25.25 & 101.55 \\
\hline Minimum & 0.05 & 0.00 & 0.02 & 33.51 & 0.00 & 0.09 & 0.00 & 0.29 & 3.79 & 0.00 & 0.00 & 0.00 & 97.18 \\
\hline Mean & 0.73 & 014 & 0.16 & 49.05 & 0.02 & 0.72 & 2.96 & 0.50 & 37.01 & 0.01 & 0.03 & 8.22 & 99.55 \\
\hline 227 & 2 & & 0 & & & & & 0 & 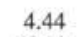 & 0 & 0. & 0.00 & 95.78 \\
\hline $227 \mathrm{~F}$ & 14.03 & & 0.3 & & 0.1 & & & & 16. & 0. & 0.01 & 0.00 & 94.98 \\
\hline 19IR-1, 25-al-hiTi-1 & 1.52 & 0.01 & 0.12 & 90.89 & 0.03 & 2. & 0.03 & 0.79 & 3.12 & 0.00 & 0.01 & 0.00 & 98.88 \\
\hline 202R-1, 56-a-hiTi-1 & 0.13 & 0.00 & 0.07 & 92.61 & 0.05 & 0.71 & 0.02 & 0.82 & 3.35 & 0.00 & 0.00 & 0.00 & 97.76 \\
\hline Maximum & 6.51 & 0.03 & 0.20 & 76.37 & 0.07 & 5.70 & 0.03 & 0.85 & 7.36 & 0.00 & 0.01 & 0.00 & 97.12 \\
\hline & 4.63 & 0.01 & 0.17 & 82.18 & 0.05 & 4.5 & 0.02 & 0.83 & 5.15 & 0.00 & 0.01 & 0.00 & 97.65 \\
\hline Mean & 10.37 & 0.02 & 0.30 & 68.87 & 0.07 & 9.56 & 0.02 & 0.86 & 6.77 & 0.00 & 0.02 & 0.00 & 96.85 \\
\hline
\end{tabular}

\begin{tabular}{|c|c|c|c|c|c|c|c|c|}
\hline Analysis & $\begin{array}{c}\mathrm{SiO}_{2} \\
(\mathrm{wt} \%)\end{array}$ & $\begin{array}{c}\mathrm{MgO} \\
\text { (wt\%) }\end{array}$ & $\begin{array}{c}\mathrm{CaO} \\
(\mathrm{wt} \%)\end{array}$ & $\begin{array}{l}\mathrm{MnO} \\
(\mathrm{wt} \%)\end{array}$ & $\begin{array}{c}\mathrm{TiO}_{2} \\
(\mathrm{wt} \%)\end{array}$ & $\begin{array}{c}\mathrm{FeO} \\
\text { (wt\%) }\end{array}$ & $\begin{array}{c}\mathrm{H}_{2} \mathrm{O} \\
(\mathrm{wt} \%)\end{array}$ & $\begin{array}{l}\text { Totals } \\
\text { (wt\%) }\end{array}$ \\
\hline \multicolumn{9}{|l|}{ 140-504B- } \\
\hline 202R-1, 56-a-tita-1 & 29.42 & 0.00 & 27.36 & 0.04 & 39.44 & 1.98 & 4.97 & 103.21 \\
\hline 202R-1, 56-a-tita-2 & 30.24 & 0.00 & 27.78 & 0.11 & 38.61 & 2.33 & 5.01 & 104.08 \\
\hline 202R-1, 56-a-tita-3 & 30.69 & 0.03 & 28.87 & 0.00 & 37.63 & 0.35 & 4.97 & 102.54 \\
\hline 191R-1, 23-a3-tita-1 & 26.23 & 0.03 & 24.25 & 0.01 & 44.04 & 1.71 & 4.87 & 101.14 \\
\hline 191R-1, 23-a3-tita-2 & 29.48 & 0.36 & 26.52 & 0.05 & 30.93 & 5.69 & 4.64 & 97.67 \\
\hline $191 \mathrm{R}-1,25$-b1-tita-1 & 21.97 & 0.00 & 20.40 & 0.23 & 41.35 & 16.05 & 4.72 & 104.72 \\
\hline 213R-1, 75-a2-tita-1 & 27.56 & 0.00 & 25.44 & 0.01 & 35.62 & 7.39 & 4.74 & 100.76 \\
\hline 213R-1, 75-a2-tita-2 & 28.04 & 0.00 & 26.26 & 0.05 & 39.00 & 3.34 & 4.86 & 101.55 \\
\hline 213R-1, 75-al-tita-1 & 30.52 & 0.00 & 28.41 & 0.00 & 38.95 & 1.43 & 5.04 & 104.35 \\
\hline $227 \mathrm{R}-1,101-$ d-tita-1 & 28.87 & 0.01 & 27.67 & 0.10 & 31.30 & 4.28 & 4.60 & 96.83 \\
\hline 227R-1, 101-d-tita-2 & 15.59 & 0.04 & 16.39 & 1.63 & 36.85 & 29.50 & 4.34 & 104.34 \\
\hline $227 \mathrm{R}-1,101-\mathrm{d}-\mathrm{tita}-3$ & 28.86 & 2.80 & 23.05 & 0.06 & 29.98 & 9.32 & 4.65 & 98.72 \\
\hline Maximum & 30.69 & 2.80 & 28.87 & 1.63 & 44.04 & 29.50 & 5.04 & 104.72 \\
\hline Minimum & 15.59 & 0.00 & 16.39 & 0.00 & 29.98 & 0.35 & 4.34 & 96.83 \\
\hline Mean & 27.29 & 0.27 & 25.20 & 0.19 & 36.98 & 6.95 & 4.78 & 101.66 \\
\hline
\end{tabular}

Notes: magn = magnetite; ilme = ilmenite; hiTi = high-titanium; tita = titanite analyses .

REFERENCES ${ }^{\circ}$

Ade-Hall, J.M., Palmer, H.C., and Hubbard, T.P., 1971. The magnetic and opaque petrological response of basalts to regional hydrothermal alteration. Geophys. J. R. Astron. Soc., 24:137-174.

\footnotetext{
Abbreviations for names of organizations and publications in ODP reference lists follow the style given in Chemical Abstracts Service Source Index (published by American Chemical Society).
}

Alt, J.C., Honnorez, J., Laverne, C, and Emmermann, R., 1986. Hydrothermal alteration of a $1 \mathrm{~km}$ section through the upper oceanic crust, Deep Sea Drilling Project Hole 504B: mineralogy, chemistry, and evolution of seawater-basalt interactions. J. Geophys. Res., 91:10309-10335.

Anderson, R.N., Honnorez, J., Becker, K., Adamson, A.C., Alt, J.C., Emmermann, R., Kempton, P.D., Kinoshita, H., Laverne, C., Mottl, M.J., and Newmark, R.L., 1982. DSDP Hole 504B, the first reference section over $1 \mathrm{~km}$ through Layer 2 of the oceanic crust. Nature, 300:589-594.

Anderson, R.N., Honnorez, J., Becker, K., et al., 1985. Init. Repts. DSDP, 83: Washington (U.S. Govt. Printing Office). 
Becker, K., Foss, G., et al., 1992. Proc. ODP, Init. Repts., 137: College Station, TX (Ocean Drilling Program).

Becker, K., Sakai, H., Adamson, A.C., Alexandrovich, J., Alt, J.C., Anderson, R.N., Bideau, D., Gable, R., Herzig, P.M., Houghton, S., Ishizuka, H., Kawahata, H., Kinoshita, H., Langseth, M.G., Lovell, M.A., Malpas, J., Masuda, H., Merrill, R.B., Morin, R.H., Mottl, M.J., Pariso, J.E., Pezard, P., Phillips, J., Sparks, J., and Uhlig, P., 1989. Drilling deep into the oceanic crust at Hole 504B, Costa Rica Rift. Rev. Geophys., 27:79-102.

Becker, K., Sakai, H., et al., 1988. Proc. ODP, Init. Repts., 111: College Station, TX (Ocean Drilling Program).

, 1989. Proc. ODP, Sci. Results, 111: College Station, TX (Ocean Drilling Program).

Cann, J.R., Langseth, M.G., Honnorez, J., Von Herzen, R.P., White, S.M., et al., 1983. Init. Repts. DSDP, 69: Washington (U.S. Govt. Printing Office),

Cisowski, S., 1980. The relationship between the magnetic properties of terrestrial igneous rocks and the composition and internal structure of their component Fe-oxide grains. Geophys. J. R. Astron. Soc., 60:107-122.

CRRUST (Costa Rica Rift United Scientific Team), 1982. Geothermal regimes of the Costa Rica Rift, east Pacific, investigated by drilling, DSDP-IPOD Legs 68, 69, and 70. Geol. Soc. Am. Bull., 93:862-875.

Day, R., Fuller, M., and Schmidt, V.A., 1977. Hysteresis properties of titanomagnetites: grain-size and compositional dependence. Phys. Earth Planet. Inter., 13:260-267.

Deer, W.A., Howie, R.A., and Zussman, J., 1962. Rock-forming Minerals (Vol. 5): Non-silicates: London (Longman Group Ltd.).

Dick, H.J.B., Erzinger, J., Stokking, L.B., et al., 1992, Proc. ODP, Init. Repts., 140: College Station, TX (Ocean Drilling Program).

Dunlop, D.J., 1969. Hysteretic properties of synthetic and natural monodomain grains. Philos. Mag., 19:329-338.

Evans, M.E., and Wayman, M.L., 1974. An investigation of the role of ultra-fine titanomagnetite intergrowths in paleomagnetism. Geophys. J. R. Astron. Soc., 36:1-10.

Haggerty, S.E., 1976. Opaque mineral oxides in terrestrial igneous rocks. In Rumble, D., III (Ed.), Oxide Minerals: Mineral. Soc. Am., Short Course Notes, 3:101-277.

Hobart, M.A., Langseth, M.G., and Anderson, R.N., 1985. A geothermal and geophysical survey on the south flank of the Costa Rica Rift: Sites 504 and 505. In Anderson, R.N., Honnorez, J., et al., Init. Repts. DSDP, 83: Washington (U.S. Govt. Printing Office), 379-404.
Johnson, H.P., and Hall, J.M., 1978. A detailed rock magnetic and opaque mineralogy study of the basalts from the Nazca Plate. Geophys. J. R. Astron. Soc., 52:45-64.

Kempton, P.D., Autio, L.K., Rhodes, J.M., Holdaway, M.J., Dungan, M.A., and Johnson, P., 1985. Petrology of basalts from Hole 504B, Deep Sea Drilling Project, Leg 83. In Anderson, R.N., Honnorez, J., Becker, K., et al., Init. Repts. DSDP, 83: Washington (U.S. Govt. Printing Office), 129-164.

Kikawa, E., and Pariso, J.E., 1991. Magnetic properties of gabbros from Hole 735B, Southwest Indian Ridge. In Von Herzen, R.P., Robinson, P.T., et al., Proc. ODP, Sci. Results, 118: College Station, TX (Ocean Drilling Program), 285-307.

Leinen, M., Rea, D.K., et al., 1986. Init. Repts. DSDP, 92: Washington (U.S. Govt. Printing Office).

Pariso, J.E., and Johnson, H.P., 1989. Magnetic properties and oxide petrography of the sheeted dike complex in Hole 504B. In Becker, K., Sakai, H., et al., Proc. ODP, Sci. Results, 111: College Station, TX (Ocean Drilling Program), 159-167.

- H.P. 1991. Alteration processes at Deep Sea Drilling Project/Ocean Drilling Program Hole 504B at the Costa Rica Rift: implications for magnetization of oceanic crust. J. Geophys. Res., 96:11703-11722.

Smith, G.M., and Banerjee, S.K., 1986. The magnetic structure of the upper kilometer of the marine crust at Deep Sea Drilling Project Hole 504B, Eastern Pacific Ocean. J. Geophys. Res., 91:10337-10354.

Smith, G.M., Gee, J., and Klootwijk, C.T., 1991. Magnetic petrology of basalts from Ninetyeast Ridge. In Weissel, J., Peirce, J., Taylor, E., Alt, J., et al., Proc. ODP, Sci. Results, 121: College Station, TX (Ocean Drilling Program), 525-545.

Stacey, F.D., and Banerjee, S.K., 1974. Developments in Solid Earth Geophysics (Vol. 5): The Physical Principles of Rock Magnetism: Elsevier (New York).

Date of initial receipt: 28 July 1993

Date of acceptance: 3 November 1993

Ms 137/140SR-029 


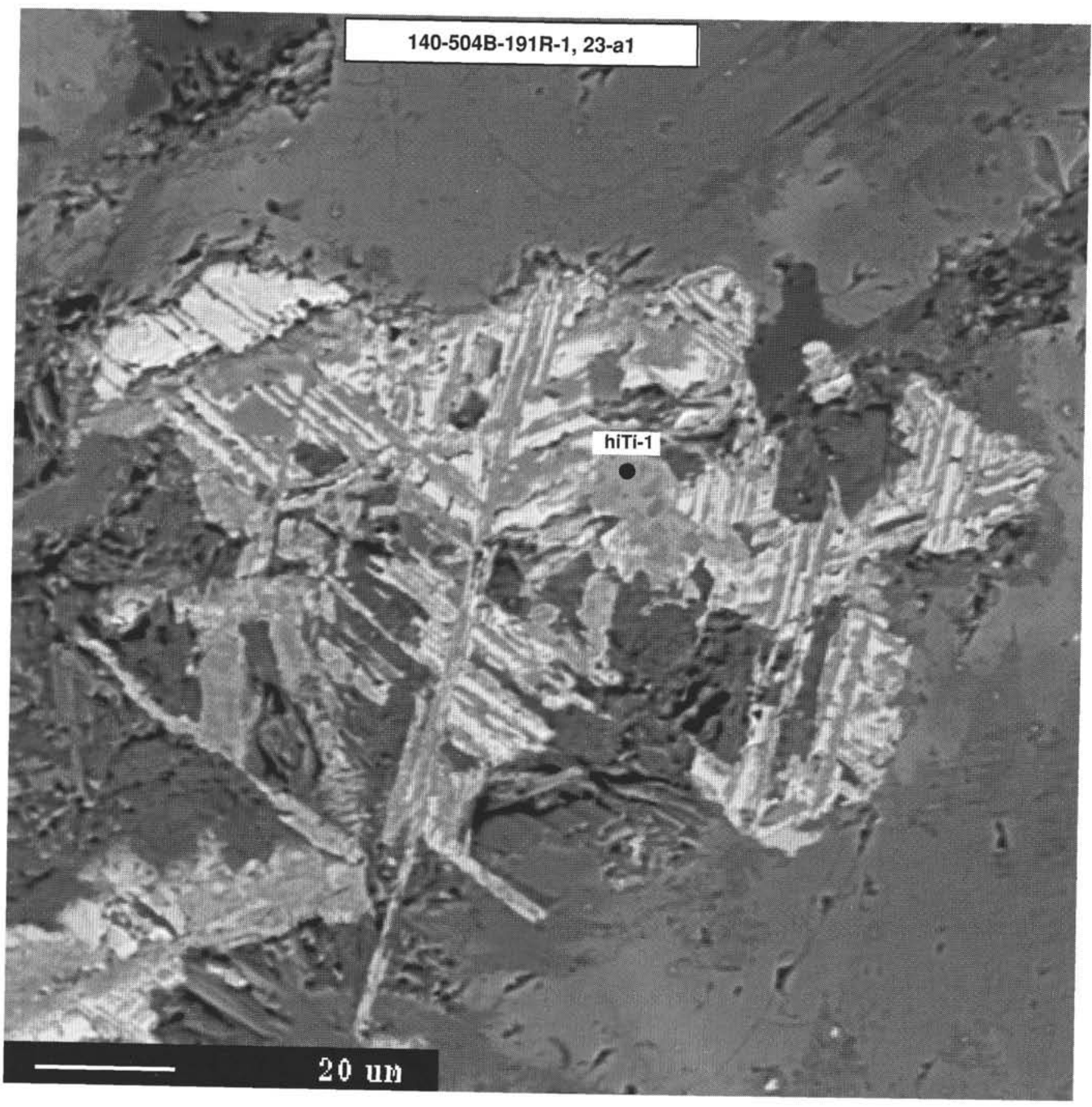

Figure 6. Back-scattered electron images. Labels correspond to analyses in Table 3. 


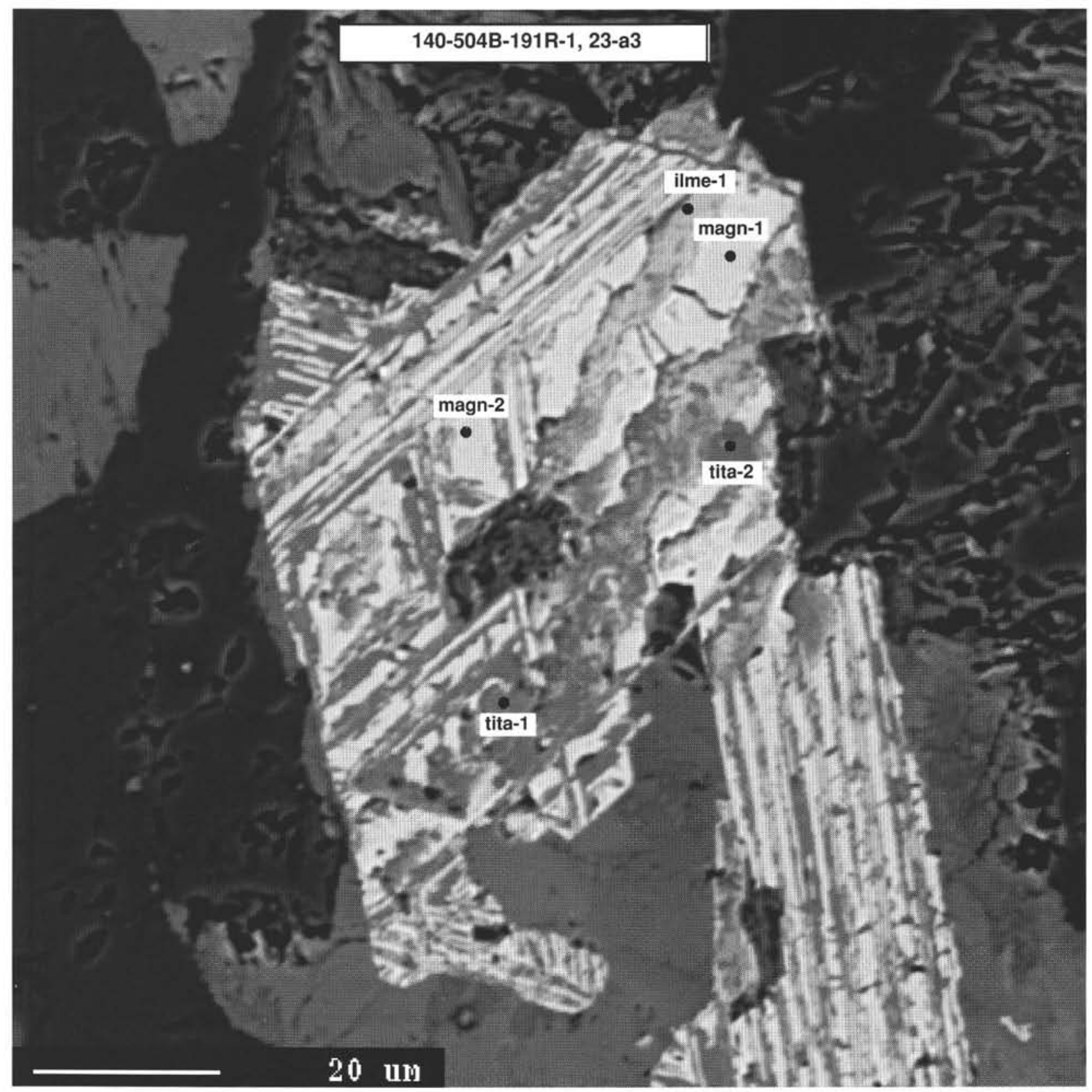

Figure 6 (continued). 


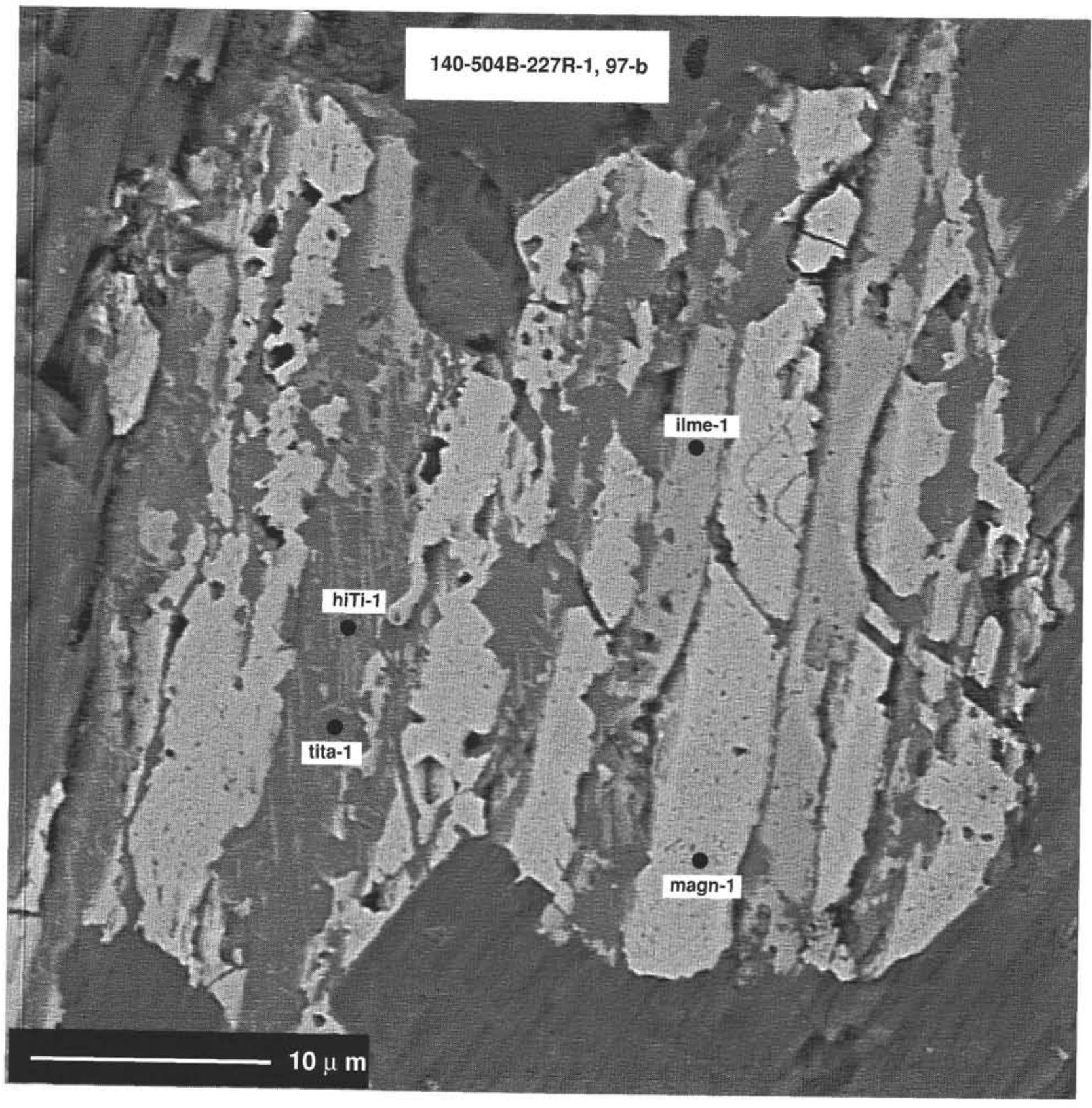

Figure 6 (continued). 